\title{
Evaluasi Pembangunan Sistem Visualisasi Data (Studi Kasus: Pengelolaan Data pada Kementerian Dalam Negeri Indonesia)
}

\author{
MUHAMMAD FIKRY ABYADL, SUMARNO, INDRIANAWATI \\ Jurusan Teknik Geodesi \\ FTSP - Institut Teknologi Nasional, Bandung \\ Email: mf.abyadl@gmail.com
}

\begin{abstract}
ABSTRAK
Pembangunan sistem visualisasi data (vista) Kemendagri merupakan langkah awal pengolahan data dan informasi Kemendagri oleh Pusdatinkomtel untuk menyederhanakan, mempermudah, mempercepat, memanipulasi, serta mengolah data dan informasi menjadi berbagai variasi penyajian data. Kebutuhan penyajian data dan informasi pada sistem vista disesuaikan dengan tugas pokok dan fungsi unit kerja di lingkungan Kemendagri. Tujuan penelitian ini adalah untuk mengevaluasi pembangunan sistem vista Kemendagri terkait data, metode, dan implementasi visualisasi data. Metode penelitian yang digunakan adalah metode top-down, yaitu metode analisis kebutuhan data yang diturunkan berdasarkan tupoksi yang telah terbentuk di instansi tersebut. Hasil identifikasi data berdasarkan tupoksi Kemendagri selanjutnya dibandingkan dengan hasil identifikasi sistem vista Kemendagri sehingga dapat dilakukan analisis kesesuaian data. Dari hasil analisis tersebut, dapat diketahui bahwa sistem vista Kemendagri baru memenuhi $71,11 \%$ dari kebutuhan penyajian data dan informasi di lingkungan Kemendagri. Hal tersebut dikarenakan setiap kategori pada sistem vista masih terdapat kekosongan data sehingga belum memenuhi keseluruhan kebutuhan penyajian data.
\end{abstract}

Kata kunci: visualisasi data, sistem visualisasi data, kementerian dalam negeri

\begin{abstract}
Development of the Ministry of Home Affair's data visualization system by Pusdatinkomtel is a first step in processing the Ministry of Home Affair's data and information. The development aims to simplify, accelerate, facilitate, manipulate and process data and information into various data visualizations. Data and information visualization necessity develops in agreement with basic task and function of work unit in the Ministry of Home Affair's. This study aims to evaluate development of the Ministry of Home Affair's data visualization system related to the data, method, and implementation of data visualization. The research method in this study uses a top-down method. The method analyses data needs based on the basic task and function of work unit in the Ministry of Home Affairs. Furthermore, data suitability analysis is done by comparing result of data identification based on the basic task and function of Ministry of Home Affair's with data visualization system. The analysis result shows the Ministry of Home Affair's data visualization system only fulfilling $71.11 \%$ from the data and information visualization necessity in the Ministry of Home Affair's. This is because each category in data visualization system still has data gaps so it has not met the overall needs of data visualization.
\end{abstract}

Keywords: data visualization, data visualization system, ministry of home affairs 


\section{PENDAhUlUan}

Kementerian Dalam Negeri (Kemendagri) merupakan salah satu kementerian di dalam Kabinet Kerja Pemerintah Republik Indonesia periode 2014-2019 yang membidangi urusan pemerintahan dalam negeri. Berdasarkan Peraturan Presiden Republik Indonesia Nomor 11 Tahun 2015 (Presiden RI, 2015) tentang Kementerian Dalam Negeri dan didetailkan dengan Peraturan Menteri Dalam Negeri Republik Indonesia Nomor 43 Tahun 2015 Tentang Organisasi dan Tata Kerja Kementerian Dalam Negeri, disebutkan bahwa Kemendagri mempunyai tugas untuk menyelenggarakan urusan di bidang pemerintahan dalam negeri untuk membantu Presiden dalam menyelenggarakan pemerintahan negara (Kemendagri RI, 2015). Dalam melaksanakan tugasnya, Kemendagri menyelenggarakan 10 fungsinya, yaitu menyelenggarakan fungsi perumusan, penetapan, dan pelaksanaan kebijakan di bidang politik dan pemerintahan umum, otonomi daerah, pembinaan administrasi kewilayahan, pembinaan urusan pemerintahan dan pembangunan daerah, pembinaan keuangan daerah, serta kependudukan dan pencatatan sipil, sesuai ketentuan peraturan perundang-undangan.

Dalam menjalankan tugas dan fungsinya, Kemendagri dibantu oleh 12 komponen/unit kerja yang memiliki tanggung jawab terkait dengan bidangnya masing-masing, yaitu Sekretariat Jenderal, Direktorat Jenderal Politik dan Pemerintahan Umum, Direktorat Jenderal Bina Administrasi Kewilayahan, Direktorat Jenderal Otonomi Daerah, Direktorat Jenderal Bina Pembangunan Daerah, Direktorat Jenderal Bina Pemerintahan Desa, Direktorat Jenderal Bina Keuangan Daerah, Direktorat Jenderal Kependudukan dan Pencatatan Sipil, Inspektorat Jenderal, Badan Penelitian dan Pengembangan, Badan Pengembangan Sumber Daya Manusia, dan Staf Ahli Menteri. Pusat Data, Informasi, Komunikasi dan Telekomunikasi (Pusdatinkomtel) merupakan salah satu unit kerja pusat di bawah Sekretariat Jenderal yang dibentuk dengan tugas utama untuk mengumpulkan, mengolah dan menyajikan data/informasi. Karena banyaknya data yang dikelola di Pusdatinkomtel tersebut, maka diperlukan upaya sistematik untuk membangun suatu basisdata guna mendukung kebutuhan data dan informasi yang dibutuhkan pada sebuah unit kerja di lingkungan Kemendagri, sehingga keseluruhan data dan informasi dapat terintegrasi.

Salah satu upaya untuk mengintegrasikan seluruh data dan informasi yang ada adalah dengan membangun sebuah sistem visualisasi data (vista). Statistical Analysis System (SAS) Institute (SAS Institute, 2016) mendefinisikan visualisasi data sebagai tampilan data dalam bentuk gambar atau grafik. Tujuan utama visualisasi data adalah untuk mengkomunikasikan informasi secara jelas dan efisien kepada pengguna dalam bentuk grafik informasi seperti tabel, grafik dan lain sebagainya (Friedman, 2008). Visualisasi data juga dapat dilakukan dalam bentuk peta. Melalui peta, data dapat terlihat pola persebarannya sehingga dapat dianalisis penyebab dan keterkaitan antar ruang (Nollenburg, 2007).

Pada tahun 2014, Kemendagri telah merancang dan membangun sistem visualisasi data Kementerian Dalam Negeri. Sistem ini dibangun untuk menyederhanakan, mempermudah, mempercepat, memanipulasi, serta mengolah data dan informasi Kemendagri dalam berbagai variasi penyajian data. Pembangunan sistem vista ini merupakan langkah awal pengolahan data dan informasi Kemendagri oleh Pusdatinkomtel. Data Kemendagri yang digunakan dalam pembangunan sistem vista merupakan data yang berasal dari berbagai sumber unit kerja di lingkungan Kemendagri dengan format/tipe data yang berbeda. Data tersebut disajikan menggunakan teknik visualisasi yang tepat agar pengguna dapat menerima informasi dengan jelas. Kebutuhan penyajian data dan informasi pada sistem vista disesuaikan dengan tugas pokok dan fungsi (tupoksi) unit kerja di lingkungan Kemendagri. Oleh karena itu, dalam penelitian ini akan dilakukan kegiatan untuk mengevaluasi 
pembangunan sistem visualisasi data Kemendagri terkait data, metode, dan implementasi visualisasi data.

Rumusan masalah dalam penelitian ini terdiri dari data dan informasi apa saja yang dikelola dalam sistem vista Kemendagri, bagaimana metode visualisasi data Kemendagri, dan sejauh mana sistem vista dapat memenuhi kebutuhan penyajian data dan informasi di lingkungan Kemendagri. Batasan masalah dalam evaluasi pembangunan sistem visualisasi data adalah data yang digunakan merupakan sistem vista dan tupoksi Kemendagri dan metode yang digunakan untuk mengkaji sistem visualisasi data Kemendagri adalah metode top-down.

\section{METODOLOGI}

Metodologi yang dilakukan dalam penelitian ini dapat dilihat pada Gambar 1.

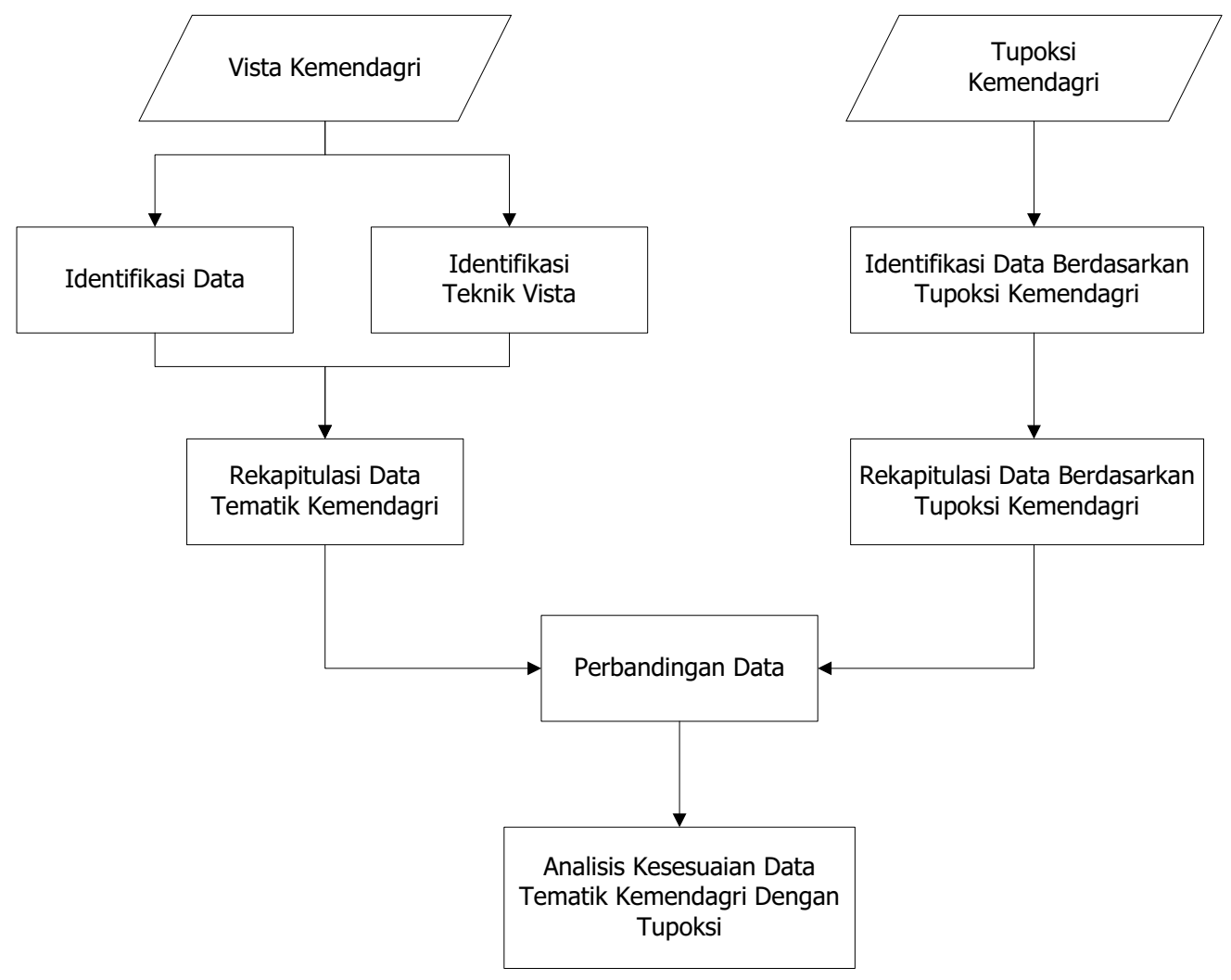

Gambar 1. Metodologi Penelitian

Berikut adalah penjelasan dari diagram alir metodologi penelitian:

1) Persiapan

Pada tahap ini, kegiatan yang dilakukan adalah persiapan data yang diperoleh dari Kemendagri yaitu sistem vista dan tupoksi dari masing-masing unit kerja di lingkungan Kemendagri.

2) Identifikasi Data

Kegiatan yang dilakukan adalah mengidentifikasi jenis data tematik yang ada dalam sistem vista Kemendagri.

3) Identifikasi Teknik Vista

Data tematik yang ditampilkan pada sistem vista Kemendagri mempunyai bentuk penyajian data yang beragam. Kegiatan yang dilakukan pada tahap ini adalah mengidentifikasi bentuk penyajian data tematik yang ada dalam sistem tersebut. 
4) Identifikasi Data Berdasarkan Tupoksi Kemendagri

Tahap identifikasi data berdasarkan tupoksi Kemendagri adalah melakukan analisis tupoksi dari 12 (dua belas) unit kerja di lingkungan Kemendagri dengan menggunakan metode top-down sehingga diperoleh hasil berupa jenis data tematik yang dihasilkan dan digunakan di lingkungan Kemendagri. Metode top-down yaitu suatu proses pengkajian yang diturunkan berdasarkan tugas pokok dan fungsi yang telah terbentuk di instansi tersebut. Pendekatan metode top-down ini diadopsi dari Sumarno dan Indrianawati (2011) dan diterapkan untuk mengkaji pembangunan sistem vista ini karena:

a. Skala lingkungannya yang luas sehingga tercapai efisiensi dalam pelaksanaan programnya;

b. Dilakukan oleh pemerintah yang memiliki otoritas dan kapasitas sehingga dalam pelaksanaan programnya dapat dilakukan secara efektif;

c. Proses perencanaan dan pelaksanaannya menggunakan waktu yang relatif cepat;

d. Proses perencanaan dan pelaksanaannya menggunakan biaya yang relatif lebih murah;

e. Tepat untuk skala wilayah yang lebih luas (nasional, provinsi); dan

f. Tepat untuk jenis kebijakan yang tidak memungkinkan terjadinya consensus.

5) Perbandingan Data

Kegiatan yang dilakukan adalah membandingkan data hasil identifikasi sistem vista dengan data hasil identifikasi berdasarkan tupoksi unit kerja di lingkungan Kemendagri.

6) Analisis Kesesuaian Data Tematik Kemendagri Dengan Tupoksi.

Berdasarkan data perbandingan hasil identifikasi sistem vista dengan hasil identifikasi data berdasarkan tupoksi unit kerja di lingkungan Kemendagri, maka dapat dilakukan analisis kesesuaian data tematik Kemendagri dengan tupoksi Kemendagri.

\section{HASIL DAN PEMBAHASAN}

\subsection{Visualisasi Data Kemendagri}

Dari hasil identifikasi data dapat diketahui bahwa data tematik yang digunakan dalam sistem vista Kemendagri berjumlah 39 (tiga puluh sembilan), yang terdiri atas 9 (sembilan) kategori seperti yang dapat dilihat pada Tabel 1 .

Tabel 1. Kategori Data Vista Kemendagri

\begin{tabular}{clc}
\hline No. & \multicolumn{1}{c}{ Kategori } & $\begin{array}{c}\text { Jumlah Data } \\
\text { Tematik }\end{array}$ \\
\hline 1 & Pusdatinkomtel & 7 \\
2 & Otonomi Daerah & 3 \\
3 & Kesatuan Bangsa Politik & 10 \\
4 & Keuangan Daerah & 7 \\
5 & Pemerintahan Umum & 2 \\
6 & Pembangunan Daerah & 1 \\
7 & Kependudukan dan Catatan Sipil & 4 \\
8 & Pemberdayaan Masyarakat dan Desa & 2 \\
9 & Institut Pemerintahan Dalam Negeri (IPDN) & 3 \\
\hline \multicolumn{2}{c}{ Jumlah } \\
\hline
\end{tabular}


Data tematik yang terdapat dalam 9 (sembilan) kategori data vista Kemendagri dijabarkan sebagai berikut:

1) Pusdatinkomtel, terdapat 7 (tujuh) data tematik, yaitu data fasilitas kesehatan (jumlah sarana kesehatan), daftar pemilih tetap pemilihan legislatif (pileg), jumlah data satuan pendidikan (sekolah) anak usia dini, jumlah data satuan pendidikan (sekolah) dasar hingga menengah, jumlah data satuan pendidikan (sekolah tinggi), jumlah data satuan pendidikan (sekolah khusus), dan data fasilitas kesehatan (jumlah tenaga medis).

2) Otonomi Daerah, terdapat 3 (tiga) data tematik, yaitu hasil pemilukada, penetapan peringkat, dan pilkada serentak.

3) Kesatuan Bangsa Politik, terdapat 10 (sepuluh) data tematik, yaitu hasil rekapitulasi perolehan suara pasangan calon presiden dan calon wakil presiden, rekapitulasi pemilu, rekapitulasi pembentukan Forum Kewaspadaan Dini Masyarakat (FKDM) kabupaten/kota, rekapitulasi pembentukan Forum Kewaspadaan Dini Masyarakat (FKDM) provinsi, rekapitulasi pembentukan Forum Pembauran Kebangsaan (FPK) kabupaten/kota, rekapitulasi pembentukan Forum Pembauran Kebangsaan (FPK) provinsi, rekapitulasi pembentukan Forum Kerukunan Umat Beragama (FKUB) kabupaten/kota, rekapitulasi pembentukan Forum Kerukunan Umat Beragama (FKUB) provinsi, rekapitulasi pembentukan Dewan Penasehat Forum Kerukunan Umat Beragama (DP FKUB) kabupaten/kota, dan rekapitulasi pembentukan Dewan Penasehat Forum Kerukunan Umat Beragama (DP FKUB) provinsi.

4) Keuangan Daerah, terdapat 7 (tujuh) data tematik, yaitu Anggaran Pendapatan dan Belanja Daerah (APBD) menurut penerimaan daerah, APBD menurut pengeluaran daerah, ringkasan APBD provinsi/kabupaten dan kota, APBD provinsi/kabupaten dan kota, belanja menurut urusan belanja tidak langsung dan belanja langsung, belanja menurut urusan, serta jumlah pegawai kabupaten dan kota dalam APBD.

5) Pemerintahan Umum, terdapat 2 (dua) data tematik, yaitu rekapitulasi data sarana prasarana satuan polisi pamong praja (jumlah pegawai) dan rekapitulasi data sarana prasarana satuan polisi pamong praja (deskripsi kantor/badan).

6) Pembangunan Daerah, terdapat 1 (satu) data tematik, yaitu penetapan peraturan daerah Rencana Tata Ruang Wilayah (RTRW).

7) Kependudukan dan Catatan Sipil, terdapat 4 (empat) data tematik, yaitu jumlah penduduk menurut usia, jumlah penduduk menurut agama, jumlah penduduk menurut status kawin, dan jumlah penduduk menurut jenis kelamin.

8) Pemberdayaan Masyarakat dan Desa, terdapat 2 (dua) data tematik, yaitu rekapitulasi lokasi dan alokasi Bantuan Langsung Masyarakat Program Nasional Pemberdayaan Masyarakat (BLM PNPM) mandiri dan kepala desa.

9) Institut Pemerintahan Dalam Negeri (IPDN), terdapat 3 (tiga) data tematik, yaitu data alumni IPDN angkatan I s/d XXII, data alumni IPDN menjadi kepala daerah/wakil, dan data alumni IPDN menurut eselon.

Berdasarkan pemilihan teknik visualisasi data, data tematik pada Sistem Vista Kemendagri divisualisasikan ke dalam bentuk tabel, grafik, dan peta. Tidak seluruh data tematik Kemendagri dapat divisualisasikan ke dalam 3 (tiga) bentuk penyajian data tersebut. Penjelasan dari bentuk penyajian data atau teknik visualisasi data tematik Kemendagri dapat dilihat pada Tabel 2.

Tabel 2. Teknik Visualisasi Data Tematik Kemendagri

\begin{tabular}{lllll}
\hline \multirow{2}{*}{ No. } & \multirow{2}{*}{ Data Tematik } & \multicolumn{3}{c}{ Visualisasi Data } \\
\cline { 3 - 5 } & & Tabel & Grafik & Peta \\
\hline 1 & Pusdatinkomtel & & & \\
& 1.1. Data Fasilitas Kesehatan (Jumlah Sarana Kesehatan) & $\sqrt{ }$ & $\sqrt{ }$ & $\sqrt{ }$ \\
\hline
\end{tabular}


Tabel 2 Teknik Visualisasi Data Tematik Kemendagri (Lanjutan)

\begin{tabular}{|c|c|c|c|c|}
\hline \multirow{2}{*}{ No. } & \multirow{2}{*}{ Data Tematik } & \multicolumn{3}{|c|}{ Visualisasi Data } \\
\hline & & Tabel & Grafik & Peta \\
\hline & 1.2. Daftar Pemilih Tetap Pemilihan Legislatif (Pileg) & $\sqrt{ }$ & $\sqrt{ }$ & $\sqrt{ }$ \\
\hline & 1.3. Jumlah Data Satuan Pendidikan (sekolah) Anak Usia Dini & $\sqrt{ }$ & $\sqrt{ }$ & $\sqrt{ }$ \\
\hline & $\begin{array}{l}\text { 1.4. Jumlah Data Satuan Pendidikan (Sekolah) Dasar Hingga } \\
\text { Menengah }\end{array}$ & $\sqrt{ }$ & $\sqrt{ }$ & $\sqrt{ }$ \\
\hline & 1.5. Jumlah Data Satuan Pendidikan (Sekolah Tinggi) & $\sqrt{ }$ & $\sqrt{ }$ & $\sqrt{ }$ \\
\hline & 1.6. Jumlah Data Satuan Pendidikan (Sekolah Khusus) & $\sqrt{ }$ & $\sqrt{ }$ & $\sqrt{ }$ \\
\hline & 1.7. Data Fasilitas Kesehatan (Jumlah Tenaga Medis) & $\sqrt{ }$ & $\sqrt{ }$ & $\sqrt{ }$ \\
\hline \multirow[t]{4}{*}{2} & Otonomi Daerah & & & \\
\hline & 2.1. Hasil Pemilukada & $\sqrt{ }$ & & \\
\hline & 2.2. Penetapan Peringkat & $\sqrt{ }$ & & \\
\hline & 2.3. Pilkada Serentak & & & $\sqrt{ }$ \\
\hline \multirow[t]{12}{*}{3} & Kesatuan bangsa Politik & & & \\
\hline & $\begin{array}{l}\text { 3.1. Hasil Rekapitulasi Perolehan Suara Pasangan Calon Capres \& } \\
\text { Cawapres }\end{array}$ & $\sqrt{ }$ & $\sqrt{ }$ & $\sqrt{ }$ \\
\hline & 3.2. Rekapitulasi Pemilu & $\sqrt{ }$ & $\sqrt{ }$ & $\sqrt{ }$ \\
\hline & $\begin{array}{l}\text { 3.3. Rekapitulasi Pembentukan Forum Kewaspadaan Dini } \\
\text { Masyarakat (FKDM) Kabupaten/Kota }\end{array}$ & $\sqrt{ }$ & $\sqrt{ }$ & $\sqrt{ }$ \\
\hline & $\begin{array}{l}\text { 3.4. Rekapitulasi Pembentukan Forum Kewaspadaan Dini } \\
\text { Masyarakat (FKDM) Provinsi }\end{array}$ & $\sqrt{ }$ & $\sqrt{ }$ & $\sqrt{ }$ \\
\hline & $\begin{array}{l}\text { 3.5. Rekapitulasi Pembentukan Forum Pembauran Kebangsaan } \\
\text { (FPK) Kabupaten/Kota }\end{array}$ & $\sqrt{ }$ & $\sqrt{ }$ & $\sqrt{ }$ \\
\hline & $\begin{array}{l}\text { 3.6. Rekapitulasi Pembentukan Forum Pembauran Kebangsaan } \\
\text { (FPK) Provinsi } \\
\text { 3.7. Rekapitulasi Pembentukan Forum Kerukunan Umat }\end{array}$ & $\sqrt{ }$ & $\sqrt{ }$ & $\sqrt{ }$ \\
\hline & $\begin{array}{l}\text { Beragama } \\
\text { (FKUB) Kabupaten/Kota }\end{array}$ & $\sqrt{ }$ & $\sqrt{ }$ & $\sqrt{ }$ \\
\hline & 3.8. Rekapitulasi Pembentukan Forum Kerukunan Umat & & & \\
\hline & $\begin{array}{l}\text { Beragama } \\
\text { (FKUB) Provinsi }\end{array}$ & $\sqrt{ }$ & $\sqrt{ }$ & $\sqrt{ }$ \\
\hline & $\begin{array}{l}\text { 3.9. Rekapitulasi Pembentukan Dewan Penasehat Forum } \\
\text { Kerukunan Umat Beragama (DP FKUB) Kabupaten/Kota }\end{array}$ & $\sqrt{ }$ & $\sqrt{ }$ & $\sqrt{ }$ \\
\hline & $\begin{array}{l}\text { 3.10. Rekapitulasi Pembentukan Dewan Penasehat Forum } \\
\text { Kerukunan Umat Beragama (DP FKUB) Provinsi }\end{array}$ & $\sqrt{ }$ & $\sqrt{ }$ & $\sqrt{ }$ \\
\hline \multirow[t]{8}{*}{4} & Keuangan Daerah & & & \\
\hline & 4.1. APBD Menurut Penerimaan Daerah & $\sqrt{ }$ & $\sqrt{ }$ & $\sqrt{ }$ \\
\hline & 4.2. APBD Menurut Pengeluaran Daerah & $\sqrt{ }$ & $\sqrt{ }$ & $\sqrt{ }$ \\
\hline & 4.3. Ringkasan APBD Provinsi/Kabupaten dan Kota & $\sqrt{ }$ & $\sqrt{ }$ & $\sqrt{ }$ \\
\hline & 4.4. APBD Provinsi/Kabupaten dan Kota & $\sqrt{ }$ & $\sqrt{ }$ & $\sqrt{ }$ \\
\hline & $\begin{array}{l}\text { 4.5. Belanja Menurut Urusan Bantuan Tidak Langsung dan } \\
\text { Bantuan Langsung }\end{array}$ & $\sqrt{ }$ & $\sqrt{ }$ & $\sqrt{ }$ \\
\hline & 4.6. Belanja Menurut Urusan & $\sqrt{ }$ & $\sqrt{ }$ & \\
\hline & 4.7. Jumlah Pegawai Kabupaten dan Kota Dalam APBD & $\sqrt{ }$ & $\sqrt{ }$ & $\sqrt{ }$ \\
\hline \multirow[t]{3}{*}{5} & Pemerintahan Umum & & & \\
\hline & $\begin{array}{l}\text { 5.1. Rekapitulasi Data Sarana Prasarana Satuan Polisi Pamong } \\
\text { Praja (Jumlah Pegawai) }\end{array}$ & $\sqrt{ }$ & $\sqrt{ }$ & $\sqrt{ }$ \\
\hline & $\begin{array}{l}\text { 5.2. Rekapitulasi Data Sarana Prasarana Satuan Polisi Pamong } \\
\text { Praja (Deskripsi Kantor/Badan) }\end{array}$ & $\sqrt{ }$ & & \\
\hline
\end{tabular}


Tabel 2 Teknik Visualisasi Data Tematik Kemendagri (Lanjutan)

\begin{tabular}{|c|c|c|c|c|}
\hline \multirow{2}{*}{ No. } & \multirow{2}{*}{ Data Tematik } & \multicolumn{3}{|c|}{ Visualisasi Data } \\
\hline & & Tabel & Grafik & Peta \\
\hline \multirow[t]{2}{*}{6} & Pembangunan Daerah & & & \\
\hline & $\begin{array}{l}\text { 6.1. Penetapan Peraturan Daerah Rencana Tata Ruang Wilayah } \\
\text { (RTRW) }\end{array}$ & $\sqrt{ }$ & & \\
\hline \multirow[t]{5}{*}{7} & Kependudukan dan Catatan Sipil & & & \\
\hline & 7.1. Jumlah Penduduk Menurut Usia & $\sqrt{ }$ & $\sqrt{ }$ & $\sqrt{ }$ \\
\hline & 7.2. Jumlah Penduduk Menurut Agaman & $\sqrt{ }$ & $\sqrt{ }$ & $\sqrt{ }$ \\
\hline & 7.3. Jumlah Penduduk Menurut Status Kawin & $\sqrt{ }$ & $\sqrt{ }$ & $\sqrt{ }$ \\
\hline & 7.4. Jumlah Penduduk Menurut Jenis Kelamin & $\sqrt{ }$ & $\sqrt{ }$ & $\sqrt{ }$ \\
\hline \multirow[t]{3}{*}{8} & Pemberdayaan Masyarakat dan Desa & & & \\
\hline & $\begin{array}{l}\text { 8.1. Rekapitulasi Lokasi dan Alokasi Bantuan Langsung } \\
\text { Masyarakat Program Nasional Pemberdayaan Masyarakat (BLM } \\
\text { PNPM) Mandiri }\end{array}$ & $\sqrt{ }$ & $\sqrt{ }$ & $\sqrt{ }$ \\
\hline & 8.2. Kepala Desa & $\sqrt{ }$ & $\sqrt{ }$ & $\sqrt{ }$ \\
\hline \multirow[t]{4}{*}{9} & Institut Pemerintahan Dalam Negeri (IPDN) & & & \\
\hline & 9.1. Data Alumni IPDN Angkatan I s/d XXII & $\sqrt{ }$ & $\sqrt{ }$ & $\sqrt{ }$ \\
\hline & 9.2. Data Alumni IPDN Menjadi Kepala Daerah/Wakil & $\sqrt{ }$ & $\sqrt{ }$ & $\sqrt{ }$ \\
\hline & 9.3. Data Alumni IPDN Menurut Eselon & $\sqrt{ }$ & $\sqrt{ }$ & $\sqrt{ }$ \\
\hline
\end{tabular}

Pemilihan teknik visualisasi data pada Sistem Vista Kemendagri dijabarkan sebagai berikut:

1) Pusdatinkomtel, keseluruhan data tematik pada kategori ini disajikan dalam bentuk tabel, grafik, dan peta.

2) Otonomi Daerah, data tematik pada kategori ini disajikan dalam bentuk tabel dan peta. Data hasil pemilukada dan data penetapan peringkat disajikan dalam bentuk tabel. Sedangkan data pilkada serentak disajikan dalam bentuk peta.

3) Kesatuan Bangsa Politik, keseluruhan data tematik pada kategori ini disajikan dalam bentuk tabel, grafik, dan peta.

4) Keuangan Daerah, data tematik pada kategori ini disajikan dalam bentuk tabel, grafik dan peta. Akan tetapi, tidak seluruh data disajikan dalam 3 (tiga) bentuk penyajian tersebut. Data APBD menurut penerimaan daerah, APBD menurut pengeluaran daerah, ringkasan APBD provinsi/kabupaten dan kota, APBD provinsi/kabupaten dan kota, belanja menurut urusan belanja tidak langsung dan belanja langsung, serta jumlah pegawai kabupaten dan kota dalam APBD disajikan dalam bentuk tabel, grafik, dan peta. Sedangkan data belanja menurut urusan disajikan dalam bentuk tabel dan grafik.

5) Pemerintahan Umum, data tematik pada kategori ini disajikan dalam bentuk tabel, grafik dan peta. Akan tetapi, tidak seluruh data disajikan dalam 3 (tiga) bentuk penyajian tersebut. Data rekapitulasi data sarana prasarana sattuan polisi pamong praja (jumlah pegawai) disajikan dalam bentuk tabel, grafik, dan peta. Sedangkan data rekapitulasi data sarana prasarana satuan polisipamong praja (deskripsi kantor/badan) disajikan dalam bentuk tabel.

6) Pembangunan Daerah, data tematik pada kategori ini disajikan dalam bentuk tabel yaitu data penetapan peraturan daerah Rencana Tata Ruang Wilayah (RTRW).

7) Kependudukan dan Catatan Sipil, keseluruhan data tematik pada kategori ini disajikan dalam bentuk tabel, grafik, dan peta.

8) Pemberdayaan Masyarakat dan Desa, keseluruhan data tematik pada kategori ini disajikan dalam bentuk tabel, grafik, dan peta. 
9) Institut Pemerintahan Dalam Negeri (IPDN), keseluruhan data tematik pada kategori ini disajikan dalam bentuk tabel, grafik, dan peta.

\subsection{Analisis}

Terkait hasil penelitian yang diperoleh selanjutnya dilakukan analisis kesesuaian data tematik Kemendagri dengan tupoksi dan analisis teknik visualisasi data.

\subsubsection{Analisis Kesesuaian Data Tematik Kemendagri dengan Tupoksi}

Analisis kesesuaian data dilakukan setelah melakukan perbandingan data hasil identifikasi data dan teknik vista dengan data hasil identifikasi berdasarkan tupoksi Kemendagri. Analisis dilakukan pada setiap kategori data yang terdapat pada Sistem Vista Kemendagri, sehingga akan didapatkan hasil akhir berupa persentase yang menunjukkan kesesuaian data kategori dengan tupoksi Kemendagri. Kesesuaian masing-masing kategori dengan tupoksi diperlihatkan pada Tabel 3.

Tabel 3. Kesesuaian Data Setiap Kategori dengan Tupoksi

\begin{tabular}{|c|c|c|c|c|c|}
\hline No. & Kategori & Unit Kerja & Tupoksi & $\begin{array}{c}\text { Vista } \\
\text { Kemendagri }\end{array}$ & $\begin{array}{c}\text { Persentase } \\
(\%)\end{array}$ \\
\hline 1 & $\begin{array}{l}\text { Kesatuan Bangsa } \\
\text { Politik }\end{array}$ & $\begin{array}{l}\text { Ditjen. Politik dan } \\
\text { Pemerintahan Umum }\end{array}$ & 41 & 23 & 56,10 \\
\hline 2 & Pusdatinkomtel & Pusdatinkomtel & 26 & 5 & 19,23 \\
\hline 3 & Keuangan Daerah & Ditjen. Keuangan Daerah & 324 & 320 & 98,77 \\
\hline 4 & $\begin{array}{l}\text { Pemberdayaan } \\
\text { Masyarakat dan Desa }\end{array}$ & $\begin{array}{l}\text { Ditjen. Bina } \\
\text { Pemerintahan Desa }\end{array}$ & 76 & 27 & 35,53 \\
\hline 5 & Otonomi Daerah & Ditjen. Otonomi Daerah & 46 & 13 & 28,26 \\
\hline 6 & IPDN & IPDN & 23 & 21 & 91,30 \\
\hline 7 & $\begin{array}{l}\text { Kependudukan dan } \\
\text { Catatan Sipil }\end{array}$ & $\begin{array}{l}\text { Ditjen. Kependudukan } \\
\text { dan Pencatatan Sipil }\end{array}$ & 70 & 29 & 41,43 \\
\hline 8 & Pembangunan Daerah & $\begin{array}{l}\text { Ditjen. Bina } \\
\text { Pembangunan Daerah }\end{array}$ & 21 & 6 & 28,57 \\
\hline \multirow[t]{2}{*}{9} & Pemerintahan Umum & $\begin{array}{l}\text { Ditjen. Politik dan } \\
\text { Pemerintahan Umum }\end{array}$ & 55 & 41 & 74,55 \\
\hline & & & 682 & 485 & \\
\hline
\end{tabular}

Dari Tabel 3 dapat diketahui bahwa data tematik Kemendagri yang disajikan pada sistem vista belum mencakup keseluruhan komponen/unit kerja di lingkungan Kemendagri. Terdapat beberapa komponen/unit kerja yang tidak dapat dilakukan analisis kesesuaian data dikarenakan tidak adanya data tematik yang disajikan dalam Sistem Vista Kemendagri berdasarkan unit kerja tersebut, yaitu Direktorat Jenderal Bina Administrasi Wilayah, Badan Penelitian dan Pengembangan, Inspektorat Jenderal, Badan Pengembangan Sumber Daya Manusia, serta Staf Ahli Menteri.

\subsubsection{Analisis Teknik Visualisasi Data}

Data tematik Kemendagri divisualisasikan menggunakan teknik visualisasi data dalam bentuk tabel, grafik dan/atau peta. Pemilihan teknik didasari oleh Statistical Analysis System (SAS) mengenai Visual Analytics dan International Cartographic Association mengenai Geographic Visualization dijelaskan sebagai berikut:

1) Tabel

Data tematik Kemendagri divisualisasikan dengan teknik visualisasi data dalam bentuk tabel karena sebagian besar data tematik Kemendagri merupakan data kuantitatif yang mendeskripsikan jenis data tematik tertentu seperti jumlah penduduk, jumlah pegawai, luas wilayah, dan lain sebagainya. Data tematik tersebut dikelompokkan ke dalam 
kategori-kategori data yang disesuaikan dengan tugas pokok dan fungsi Kemendagri. Sehingga tabel yang disajikan dapat memiliki label kolom kategorial merepresentasikan nama (variabel kualitatif) dan angka (variabel kuantitatif) dengan setiap baris dari data merepresentasikan kategori dari jenis data.

2) Grafik

Teknik visualisasi data dalam bentuk grafik yang digunakan untuk memvisualisasikan data Kemendagri terdiri dari 2 (dua) macam grafik, yaitu grafik batang dan lingkaran.

a) Grafik Batang

Data Kemendagri sebagian besar berupa data statistik yang berisikan informasi mengenai jumlah dan terdiri dalam berbagai kategori, seperti: jumlah penduduk, jumlah satuan pendidikan, jumlah fasilitas kesehatan, Anggaran Pendapatan dan Belanja Daerah (APBD), dan lain sebagainya. Sehingga digunakan grafik batang untuk mempermudah dalam membandingkan jumlah yang dibedakan berdasarkan kategori atau grup serta untuk melihat pola atau keterkaitan dalam data untuk satu atau lebih variabel. Selain itu, grafik batang dapat memudahkan pengguna untuk merepresentasikan informasi yang disajikan.

b) Grafik Lingkaran

Grafik lingkaran cocok digunakan untuk menyajikan data dengan perbedaan nilai yang cukup besar. Pada Sistem Vista Kemendagri, grafik lingkaran digunakan untuk menyajikan informasi terkait jumlah dengan range yang cukup besar seperti pada kategori pemberdayaan masyarakat dan desa terdapat data tematik kepala desa yang memiliki atribut kades pria, kades wanita, sekdes PNS dan sekdes non PNS. Data tematik tersebut pada grafik batang disajikan berdasarkan masing-masing provinsi, sedangkan pada grafik lingkaran data tematik tersebut disajikan berdasarkan total keseluruhan dengan range yang lebih besar.

3) Peta

Berbeda dengan teknik visualisasi data dalam bentuk tabel dan grafik, teknik visualisasi data dalam bentuk peta menyajikan data dengan menambahkan unsur geografis dalam bentuk peta temaik. Dengan teknik ini, informasi yang disajikan tidak hanya berupa nilai statistik tetapi juga menunjukkan lokasi dari nilai tersebut. Teknik ini cocok digunakan untuk menyajikan data Kemendagri karena sebagian besar data Kemendagri memiliki informasi spasial/wilayah. Sebagai contoh pada kategori kependudukan dan catatan sipil terdapat data tematik jumlah penduduk menurut jenis kelamin. Jika menggunakan teknik visualisasi data dalam bentuk tabel dan grafik informasi yang divisualisasikan terkait data tematik tersebut hanya berupa jumlah. Sedangkan dengan teknik visualisasi data dalam bentuk petadapat menunjukkan informasi lokasi mengenai nilai tersebut.

\section{KESIMPULAN}

Sistem visualisasi data Kemendagri baru terdiri atas 485 data/informasi. Data/informasi tersebut memiliki berbagai variasi penyajian data, yaitu tabel, grafik, dan peta. Hasil dari analisis kesesuaian data menunjukkan bahwa data vista pada setiap kategori belum memenuhi kebutuhan penyajian data dan informasi berdasarkan tupoksi unit kerja di lingkungan Kemendagri. Setiap kategori memiliki persentase kesesuaian data berbeda, yaitu: Pusdatinkomtel sebesar 19,23\%, Otonomi Daerah sebesar 28,26\%, Kesatuan Bangsa Politik sebesar 56,10\%, Pemerintahan Umum sebesar 74,55\%, Keuangan Daerah sebesar 98,77\%, Pembangunan Daerah sebesar 28,57\%, Kependudukan dan Catatan Sipil sebesar 41,43\%, Pemberdayaan Masyarakat dan Desa sebesar 35,53\%, serta Institut Pemerintahan Dalam Negeri sebesar $91,30 \%$. Dari hasil analisis kesesuaian data pada setiap kategori tersebut, dapat disimpulkan bahwa data Kemendagri dalam sistem visualisasi data baru memenuhi 
kurang lebih $71,11 \%$ dari kebutuhan penyajian data dan informasi di lingkungan Kemendagri.

\section{UCAPAN TERIMA KASIH}

Penulis mengucapkan terima kasih kepada PT EFORT Digital Multisolution atas kesediaannya untuk memberikan data yang diperlukan.

\section{DAFTAR PUSTAKA}

Friedman, V. (2008). Data Visualization and Infographics. Dipetik 29 Juli 2016 dari https://www.smashingmagazine.com/2008/01/monday-inspiration-datavisualization-andinfographics/.

Nollenburg, M. (2007). Geographic Visualization. Dipetik 19 Juli 2016 dari http://tutor.nmmu.ac.za/gis/GIS421/GVIS\%203.pdf.

Kemendagri RI. (2015). Peraturan Menteri Dalam Negeri Republik Indonesia Nomor 43 Tahun 2015 Tentang Organisasi dan Tata Kerja Kementerian Dalam Negeri.

Presiden RI. (2015). Peraturan Presiden Republik Indonesia Nomor 11 Tahun 2015 tentang Kementerian Dalam Negeri.

SAS Institute. (2016). Data Visualization. Dipetik 27 Juli 2016 dari http://www.sas.com/en_sg/insights/big-data/data-visualization.html.

Sumarno dan Indrianawati. (2011). Pembangunan Geodatabase Kelautan dan Pulau-Pulau Kecil Terluar. Jurnal Rekayasa Itenas, Vol. XV, No. 1. LP2M Itenas. Bandung. 